\title{
仙台市内の応急仮設住宅における室内化学物質污染の実態 \\ FIELD INVESTIGATION ON INDOOR CHEMICAL POLLUTION IN TEMPORARY HOUSES IN SENDAI CITY
}

\author{
鍵 直 樹*, 吉野 博**, 長谷川 兼一***,

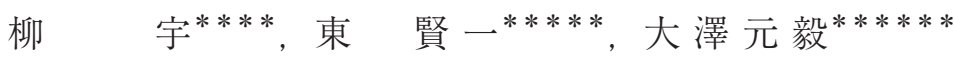 \\ Naoki KAGI, Hiroshi YOSHINO, Kenichi HASEGAWA, \\ U YANAGI, Kenichi AZUMA and Haruki OSAWA
}

\begin{abstract}
The Great East J apan Earthquake had occurred on M arch 11th in 2011. There were serious damages in Tohoku and Kanto district, especially seaside cities of the Pacific Ocean in Tohoku district by tsunami. M any people in these areas had lost their houses and more than fifty thousand temporary houses were built in three prefectures of the Tohoku district. Several problems, such as indoor thermal environment and indoor air quality as well as sound environment problems might be occurred in temporary houses.

This study aimed to investigate the indoor air quality, especially indoor volatile organic compound (VOC) concentrations in the temporary residential houses. In summer in 2011 and winter in 2012, measurements have been conducted in the temporary houses in Sendai and measuring results were compared with guideline value in J apan. As a result, total VOC (TV OC) concentrations in the most houses were over tentative guideline value in J apan, $400 \mu \mathrm{g} / \mathrm{m}^{3}$.
\end{abstract}

Keywords : Indoor air quality, Volatile organic compounds, Temporary house 室内空気質，揮発性有機化合物，応急仮設住宅

1. はじめに

新築住宅におけるシックハウス症候群の原因として, 内装材料や 什器から発生する室内空気污染物質の中でも揮発性有機化合物 (V olatile Organic Compounds: VOC) が挙げられている。室内で使用 されている建材からの化学物質の発生に加え, 住宅の気密化による 換気量の減少により, 室内空気中に污染物質が滞留し, 室内化学物 質濃度が上昇したことによって引き起こされた居住者の健康被害で ある。この対策として, 厚生労働省から 1996 年よりホルムアルデヒ ドなど 13 種類の化学物質の指針値と TVOC（総揮発性有機化合物） の暫定目標值が示された。更に 2003 年の建築基準法の改正では, ホ ルムアルデヒド発散建材の使用制限及び 24 時間機械換気の義務化 などが規定された。これにより，指針值に示されている化学物質に ついては，内装材料の発生量が抑制され，換気が確保されたことか ら，新築住宅では室内空気質を良好な状態に維持できるようになっ た。住宅の化学物質污染の実態調査については, 全国における 4,000 住戸を超えるホルムアルデヒド, トルエン, キシレン, エチルベン ゼン濃度に関する実態調查 ${ }^{11}$ がある。更には国土交通省により大規 模な新築住宅における室内空気中の主要な化学物質濃度の害態調查 2)が 2000 年度より 6 年間継続して行われてきた。結果として, 主要 な化学物質の濃度が指針值を超過する割合及びそれらの平均濃度に
ついては，低く抑えられるようになった。

2011 年に発生した東日本大震災により, 東北地方太平洋沿岸を中 心に多くの住宅が被災し, 応急仮設住宅が建築された。応急仮設住 宅は，災害救助法 23 条の 1 「収容施設（応急仮設住宅を含む。）の 供与」に災害救助の一環として規定されているものである。そのた め，応急仮設住宅は，建築基準法の「建築物」に当たるが，「応急仮 設建築物」として，建築基準法の規定は原則適用外ではある。よっ て, 上記のようなシックハウス症候群対策として, 建築基準法で規 定された内装材料の制限や換気設備の義務化などには当てはまらず, 室内の化学物質濃度の上昇が懸念される。

しかしながら，例えば岩手県応急仮設住宅仕様基準及び福島県応 急仮設住宅標準仕様書には，シックハウス対策に配慮した材料を使 用することなどの記載があり，一定の配慮が伺える。また，換気設 備についても，24 時間換気設備とは謳っていないものの，台所，風 呂，便所には換気扇を設置することになっており，居室においても これらの設備により一定の換気量が確保でき, 通常の住宅と同等の 性能を持つように努められている。ただし，応急仮設住宅には様々 な種類が存在し, 換気設備の稼働など住民の知識や住まい方に室内 空気環境が依存していることが考えられる。

ところで, 現在まで災害により多くの応急仮設住宅が建設され

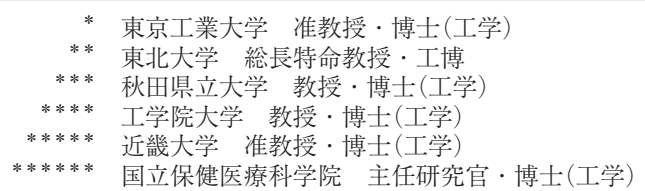

Assoc. Prof., Tokyo Institute of Technology, Dr.Eng.

President-appointed Extraordinary Prof., Tohoku University, Dr.Eng.

Prof., Akita Prefectural University, Dr.Eng.

Prof., Kogakuin University, Dr.Eng.

Assoc. Prof., Kindai University, Dr.Eng.

Chief Researcher, National Institute of Public Health, Dr.Eng. 
たものの, 応急仮設住宅における室内空気質に関する知見は, 温熱 環境に関するものに比べれば少ないのが現状である。その中でも， 大気中から二酸化窒素の侵入 ${ }^{3)}$, 建物解体時のアスベス卜飛散 ${ }^{4)}$, また今回の東日本大震災に伴う宮城県内の未入居の応急仮設住宅 5 軒における揮発性有機化合物の実測調查 ${ }^{5}$, 室内二酸化炭素濃度 ${ }^{6)}$, 微生物の現状 ${ }^{77}$, 地域別の実測の知見 ${ }^{8,9}$ がある。

そこで本研究では, 東日本大震災により建設された仙台市内の応 急仮設住宅の室内空気質, 特に化学物質の特徵を把握することを目 的に, 入居中における夏期及び冬期の応急仮設住宅内の室内空気中 におけるVOC, 空気中及び八ウスダスト中の準揮発性有機化合物 (Semi V olatile Organic Compound: SVOC) の測定を行い, その特徴 及び高濃度となった原因について検討した。

\section{2. 調查方法}

\section{1 測定対象住宅}

本調查で測定した応急仮設住宅は, Table 1 に示寸仙台市に建設さ れた建物で, 夏期 40 軒, そして冬期においても同じ住宅のうち 17 軒の居間を対象とした。1 住宅につき複数部屋ある場合には, 独立 して使用している場合には 2 箇所で， 2 部屋を 1 部屋として使用し ている場合には 1 箇所で測定を行った。夏期の実測調查は, 建設直 後の 2011 年 7 月後半より 10 月, 冬期は 2012年 3月に順次行われた。 対象とした住宅は，地区毎にメーカー，竣工時期などが異なってい る。いずれの住宅においても, 台所, 浴室, トイレに排気ファンが 設置されていた。本研究では, 応急仮設住宅の特徵から 2 種類のタ イプに分類した。プレハブ建築協会規格建築部会会員製の住宅（以 下Type 1）は，規格化された部材を用いて建築されるもので，工場 や倉庫などの応急的な建物に使用されている。この住宅については 各部屋には給気口はないことから, 台所等の排気ファンの使用によ り各部屋の隙間から流入して, 換気されているものと考えられる。 なお，このタイプの住宅には天井裏に換気設備が備え付けられてい るが，これは居室の換気に使用されるものではなく，冬期に小屋裏 で発生する結露を防止するためものである。一方，プレハブ建築協 会規格住宅部会会員製の住宅（以下 Type 2) は，一般的な住宅に用 いる部材を用いた仕様で, 換気対策としては居室外壁に面している 壁に給気口が設けてあるため，台所等の排気ファンにより各部屋の 換気が行われるように計画されている。また，冬期の測定を行った 住宅においては, 暖房器具の VOC 発生を考慮し, 燃焼による排ガ スのないエアコン・電気ストーブを使用しているか, 開放型の石油・ ガスストーブを使用しているかを確認し，Table 1 に示している。

\section{2 測定方法}

空気中の VOC の測定には, 30 分程度のアクティブサンプリング 法により行った。居住状態であれば, 室内の平均濃度として 24 時間 のパッシブサンプリング法もあるが，本研究では実測に際し，短時 間にその他の測定項目と平衡して行うために，短時間で採取できる アクティブサンプリング法を選択した。なお居住者の方には, 通常 の住まい方（換気扇の使用の有無など）を行いながら，事前には空 開け換気を行わず，室内が暑い場合，寒い場合には普段用いている 冷暖房設備を使用して頂くように要請し, 室内換気条件の統一を図 った。

捕集及び分析については, ホルムアルデヒドなどのカルボニル化
Table 1 Outline of temporary houses measured in this study

\begin{tabular}{|c|c|c|c|c|c|c|}
\hline \multirow{2}{*}{ ID } & \multirow{2}{*}{ Room layout } & \multirow{2}{*}{ Type } & \multicolumn{2}{|c|}{ Heating appliance } & \multicolumn{2}{|c|}{ Measurement } \\
\hline & & & Stove & $\mathrm{A} / \mathrm{C}$ & Summer & Winter \\
\hline 2 & 2DK & 2 & & & 0 & \\
\hline 3,23 & $2 \mathrm{DK}+2 \mathrm{DK}$ & 2 & & & o & \\
\hline 4 & 2DK & 2 & & 0 & o & 0 \\
\hline 6 & 2DK & 2 & & & o & \\
\hline 8 & $2 \mathrm{DK}$ & 2 & & & o & \\
\hline 9 & $2 \mathrm{DK}$ & 2 & & o & o & 0 \\
\hline 21 & $2 \mathrm{DK}$ & 2 & & & o & \\
\hline 22 & $2 \mathrm{DK}$ & 2 & & 0 & o & 0 \\
\hline 25 & $2 \mathrm{DK}$ & 2 & o & & o & o \\
\hline 26 & $2 \mathrm{DK}$ & 2 & o & & o & o \\
\hline 29 & 2DK & 2 & & & 0 & \\
\hline 36 & $2 \mathrm{DK}$ & 2 & & o & o & 0 \\
\hline 44 & 2DK & 2 & & & $\circ$ & \\
\hline 45 & 2DK & 2 & & & o & \\
\hline 49 & 2DK & 2 & & & o & \\
\hline 53 & 2DK & 2 & & & o & \\
\hline 58 & $2 \mathrm{DK}$ & 2 & & 0 & o & 0 \\
\hline 60 & $2 \mathrm{DK}$ & 2 & & & o & \\
\hline 63 & $2 \mathrm{DK}$ & 2 & & & 0 & \\
\hline 64 & $2 \mathrm{DK}$ & 2 & & & 0 & \\
\hline 65 & $2 \mathrm{DK}$ & 2 & o & & o & 0 \\
\hline 66 & $2 \mathrm{DK}$ & 2 & & o & o & o \\
\hline 76 & $2 \mathrm{DK}$ & 1 & 0 & & o & o \\
\hline 78 & $2 \mathrm{DK}$ & 1 & o & & 0 & o \\
\hline 79 & 1DK & 1 & & & 0 & \\
\hline 81 & 1DK & 1 & & 0 & 0 & 0 \\
\hline 83 & 2DK & 1 & & ○ & ० & ○ \\
\hline 89 & IDK & 1 & 0 & & 0 & o \\
\hline 91 & $3 \mathrm{~K}$ & 1 & & & o & \\
\hline 102 & 2DK & 2 & & & o & \\
\hline 103 & $2 \mathrm{DK}$ & 2 & & & ○ & \\
\hline 111 & $2 \mathrm{DK}$ & 1 & & 0 & 0 & 0 \\
\hline 115 & $3 \mathrm{~K}$ & 1 & & ○ & 0 & o \\
\hline 117 & 1DK & 1 & & & ○ & \\
\hline 118 & 2DK & 1 & 0 & & ○ & 0 \\
\hline 122 & 2DK & 1 & & & 0 & \\
\hline 127 & $2 \mathrm{DK}$ & 1 & & & 0 & \\
\hline 130 & 2DK & 1 & & & ○ & \\
\hline 133 & 2DK & 1 & & & 0 & \\
\hline 146 & $3 K$ & 1 & & & 0 & \\
\hline
\end{tabular}

合物には, DNPH カートリッジにより $1 \mathrm{~L} / \mathrm{min}$.で 30 分程度の捕集を 行い, 溶媒抽出後 HPLC により分析した。また, その他の VOC 及 びガス状 SVOC については, TenaxTA を用いて $0.1 \mathrm{~L} / \mathrm{min}$.で 30 分程 度の捕集を行い, 加熱脱着法で GC/MS に導入し，分析した。TVOC 濃度は, 日本建築学会基準 ${ }^{10}$ に従い, ヘキサンからへキサデカンま で検出されたピークの合計をトルエン換算して算出した。また，参 考までにそれぞれの地区では最低 1 箇所で外気の測定も行った。

ハウスダスト中に含まれるSVOCについても測定を行った。ハウ スダストの採取については, 掃除機ノズル先端に直接織込みろ紙を 装着し，掃除機からの污染を排除した簡便な方法とした。各住宅の 居間において約 $2 \mathrm{~m}^{2}$ を 2 分程度の採取を行い, $63 \mu \mathrm{m}$ のふるいをか けた後, 八ウスダストの一部を秤量後, 空の捕集管に入れ，加熱脱 着装置で GC/MS に導入し，分析した。

\section{3. 実測結果}

\section{1 室内空気中 VOC 濃度}

Table 2 に全ての実測值における厚生労働省で指針值として示さ 
Table 2 Minimum, mean and maximum concentrations of VOCs

\begin{tabular}{|c|c|c|c|c|}
\hline & Guideline & Min. & Mean & Max. \\
\hline Formaldehyde & 100 & n.d. & 22.0 & 66.6 \\
\hline Acetaldehyde & 48 & n.d. & 21.7 & 87.3 \\
\hline Toluene & 260 & 3.8 & 68.6 & 276.3 \\
\hline Ethylbenzene & 3800 & 2.7 & 16.2 & 109.7 \\
\hline Xylene & 870 & 3.5 & 19.0 & 162.8 \\
\hline Styrene & 220 & n.d. & 18.7 & 96.7 \\
\hline p-dichloro Benzene & 240 & n.d. & 175.5 & 699.8 \\
\hline Tetradecane & 330 & n.d. & 60.6 & 493.1 \\
\hline a-Pinene & & n.d. & 88.6 & 810.4 \\
\hline 2-ethyl-1-Hexanol & & n.d. & 92.8 & 307.9 \\
\hline d-Limonene & & n.d. & 95.1 & 563.1 \\
\hline TVOC & $400^{*}$ & 263.2 & 1942.0 & 8923.7 \\
\hline
\end{tabular}

*Tentative guideline for TVOC n.d.: Not detected.

れているVOC 及び， $\alpha$-ピネン， d-リモネン，2-エチル-1-ヘキサノ 一ル, TVOC 濃度の最小值, 平均值及び最大值を示す。それぞれの 物質の濃度平均值は, 各指針值を大きく下回っているものの, アセ トアルデヒド, p-ジクロロベンゼン, テトラデカンについては指針 值を超過し, 比較的高い濃度の部屋があった。TVOCの平均濃度に ついては，暫定目標值 $400 \mu \mathrm{g} / \mathrm{m}^{3}$ を大きく上回る結果となった。ま た, Fig.1 においては, 各季節における厚生労働省に示されている VOC 濃度を箱ひげ図として表したものである (図中 $\mathrm{x}$ 軸に夏期: (S), 冬期：(W)と表記)。この箱ひげ図は, ロが平均值を表し, 各横線が 下から 10，25，50，75，90 パーセンタイル值を表している（以降の図 でも同様に表示)。p-ジクロロベンゼン，テトラデカンについては， 中央值に比べて平均值の濃度が高い傾向であった。p-ジクロロベン ゼンについては，建物起因ではなく，防虫剤など居住者の持ち込み による発生源であることから，住宅によって濃度が非常に高いとこ ろがあるなど，偏差が大きくなったと考えられる。また，テトラデ カンの発生源として灯油, 塗料などが考えられている。

Fig.2 に $\alpha$-ピネン, d-リモネン, 2-エチル-1-ヘキサノールの夏期 及び冬期における濃度を示す。 $\alpha$-ピネン, d-リモネンについては, アセトアルデヒドと同様に木材などから発生する物質であり，他の VOCと比較しても高い值を示した。よって, アセトアルデヒドの濃 度の高かった理由としては, 応急仮設住宅で基礎や構造材, 内装で 使用されている木材が発生源となり, 室内濃度を高めていることが 考えられる。なお, ドイツにおける $\alpha$-ピネン, d-リモネンの指針值 ${ }^{11,12)}$ は, $200 \mu \mathrm{g} / \mathrm{m}^{3}, 1000 \mu \mathrm{g} / \mathrm{m}^{3}$ であることから, 一部の住宅でのみ この濃度を超過していた。また，2-エチル-1-へキサノールの発生源 として, 塩化ビニルに含まれている可塑剤の化学反応による発生が 知られているが ${ }^{13)}$, 台所などに施工されている塩化ビニル床シート などが影響して検出していることも考えられる。ドイツにおいては 2-エチル-1-ヘキサノールの指針值 ${ }^{14)}$ として $100 \mu \mathrm{g} / \mathrm{m}^{3}$ が示されてお り, 半数近くの居室でこの濃度よりも高い值であった。

夏期及び冬期の濃度を比較すると，夏期においては温度上昇によ る発生の増加が，また冬期においても通風換気を行わないため換気 量の減少 ${ }^{15)}$ による濃度の増加が見込まれる。夏期に平均濃度の高い 物質として, p-ジクロロベンゼン, テトラデカン, $\alpha$-ピネン, 2エチル-1-ヘキサノールであった。逆に, d-リモネン, TVOC は, 夏 期よりも冬期の方が高くなっており，物質により傾向が異なること がわかった。

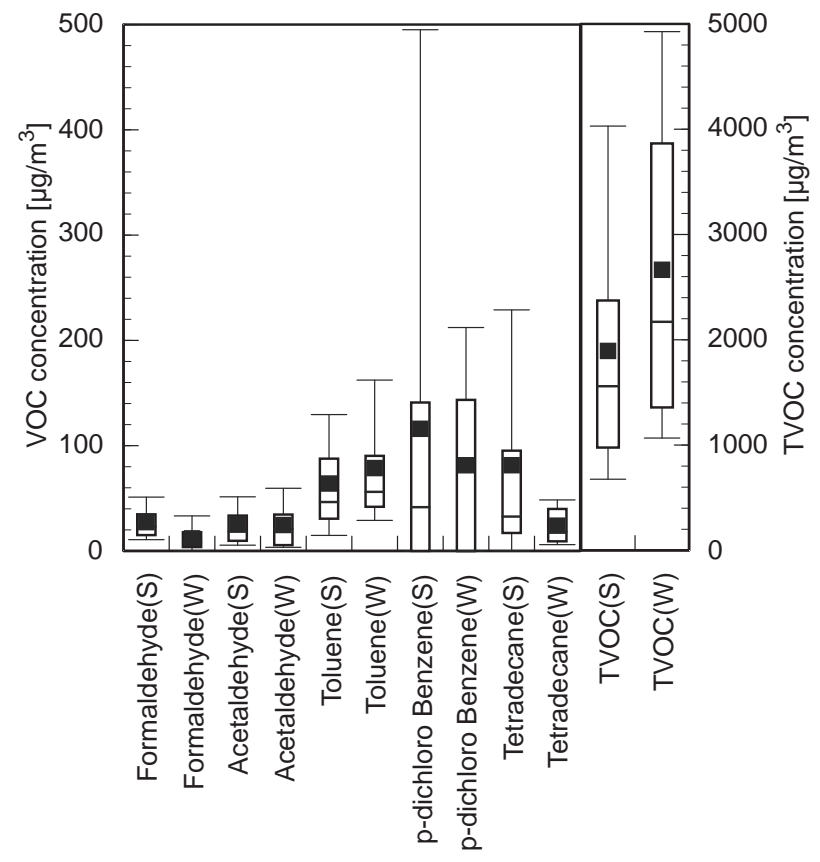

Fig.1 VOC concentrations in summer and winter

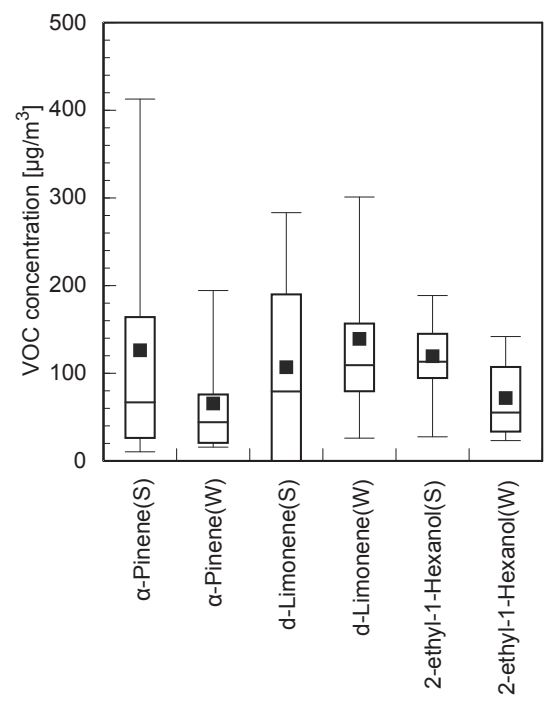

Fig.2 Concentrations of other VOCs in summer and winter

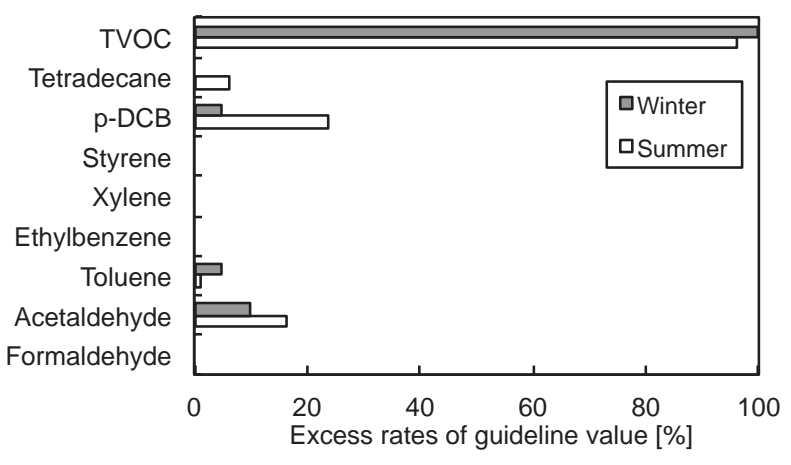

Fig.3 Excess rates of guideline values of VOCs

Fig.3 に各物質における指針值及び TVOC の暫定目標值を超過し た測定点数の割合について夏期及び冬期のデータを分けて示す。既 往の新築住宅の実態調査 ${ }^{21}$ においては, 2005 年度の指針值超過の割 
合が, ホルムアルデヒドが $1.6 \%$, アセトアルデヒド $9.7 \%$, トルエ ン $0.6 \%$ 程度であり, ホルムアルデヒド及びトルエンについては年々 減少の傾向を示していた。それに比べると, 今回の応急仮設住宅に ついては, ホルムアルデヒドでは超過する物件はなく, 適切な材料 が使用されていることが伺える。しかしながら, アセトアルデヒド では, 超過した割合が 10\%超と, 他の物質と比較しても高い割合と なっていた。上述したように住宅に使用されている木材からの発生 が考えられるが，冬期には時間が経過したことによる発生量の減少 もあり, 若干超過率が低い傾向となった。またTVOC は, 多くの住 宅において暫定目標値を超過する結果となり，冬期に測定した住宅 については全て上回る結果となった。

\subsection{SVOC の空気中及びハウスダスト中濃度}

Fig.4 に, SVOC について, フタル酸ジ-n-ブチル (DBP), フタル 酸ジ-2-エチルヘキシル（DEHP）の空気中濃度及び八ウスダスト中 の含有量について示す。室内空気中濃度については, 既往研究 ${ }^{16)}$ と 同様に蒸気圧が低いため, 指針值 (DBP: $220 \mu \mathrm{g} / \mathrm{m}^{3}$, DEHP: $120 \mu \mathrm{g} / \mathrm{m}^{3}$ ) を超過する濃度とはならず, 低い值となった。また, 冬期の方が濃 度の低い傾向となった。

ハウスダスト中の濃度では, DBPについては, 平均 $50 \mu \mathrm{g} / \mathrm{g}$ 程度 であるのに対し, DEHPについては平均 $1000 \mu \mathrm{g} / \mathrm{g}$ を超過した。既往 の研究 ${ }^{171} に お け る 30$ 件のアパートの測定では, DBPが平均 $55.6 \mu \mathrm{g} / \mathrm{g}$, DEHP が $775.5 \mu \mathrm{g} / \mathrm{g}$ であった。本調査においてもDBPよりも蒸気圧 の低いDEHP の方が濃度が高かった。また既往研究による住宅での 結果 ${ }^{18)}$ と比べても, 両者とも平均濃度は高い值となったが, 濃度範 囲としては同等であった。季節の違いは, 空気中濃度と同様に, 夏 期の方が高い值となった。

八ウスダスト中に含まれるSVOC については, 空気中の SVOC 量 と共に, 床材に堆積することによる接触の影響が原因の一つとも考 えられ ${ }^{16)}$, 塩化ビニルや自然素材 (木材) を用いた床材によっては, ハウスダスト中の含有量が異なるもの ${ }^{20,21)}$ である。今回の応急仮設 住宅の床材については, 居住者が個別に設置寸るものも含め, フロ ーリング, 畳, 塩ビシートなど様々な材料が使用され, SVOC の発 生源としても多様であったため, DEHP の含有量に大きな偏差が生 じたものと考えられる。また, 含有量にはダス卜の曝露時間(履歴), 掃除の頻度などにも影響されるものと考えられ，今後詳細に検討を 行う必要がある。

\section{4. 室内 $V O C$ 濃度上昇要因の検討}

\section{1 機械換気の運転状況}

上述の結果から, 応急仮設住宅は建築基準法の適用範囲外ではあ るものの, ホルムアルデヒド濃度は低い傾向となっており, 適切な 材料の選択が行われているものと考えられる。しかし, p-ジクロロ ベンゼン及びTVOC 濃度については高い濃度の傾向となった。p-ジ クロロベンゼンは, 建物起因ではなく居住者が持ち込んだ防虫剂が 発生源であることから, 防虫剤の適切な使用と共に, 換気を適切に 行うなどして，極端に濃度が高くならないような居住者の行動も重 要となる。

この実測調査と同時に行った居住者へのアンケート ${ }^{19)}$ では, トイ レや浴室の換気扇を常時使用しているのは，35\%程度に留まってい た。なお，およそ $2 / 3$ からは「必要時のみ運転」との回答を得てい

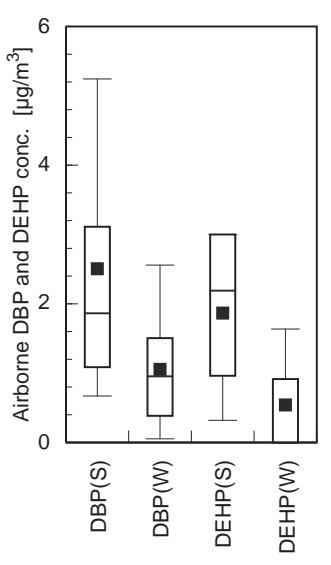

a) Airborne SVOC

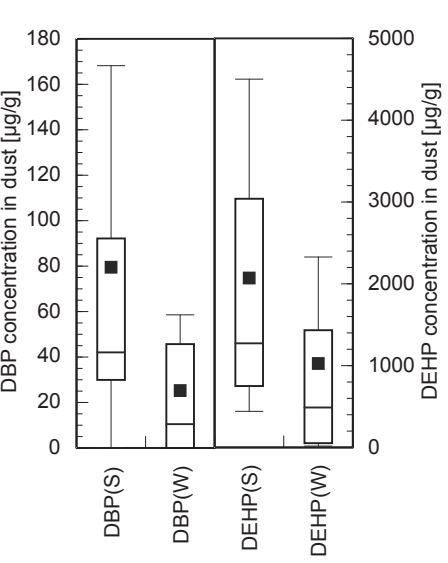

b) House-hold dust
Fig.4 SVOC concentrations in summer and winter

る。また，設置された機械換気システムは何れも第三種換気設備に 分類され，住宅自体に一定の気密性を有している場合には，居室に 適切な開口（給気口）を設け，流入から排出に至る流れを作り出す 必要がある。聞き取り調查においては, Type 2 の住宅の 4 割近くの 居住者が給気口の存在を認識しておらず，一部住戸では給気口のシ ヤッター (手動) が閉まったままになっているなど, 居住者の給気 口に対寸る認識に問題があると考えられる。このことから，換気扇 停止及び不適切な機械換気の使用方法が長く続く条件となれば，容 易に VOC 濃度が上昇するものと考えられる。冬期においては更に 空明けによる通風がされない状況であったものと考えられ，既往の 研究 ${ }^{6}$ による仮設住宅の $\mathrm{CO}_{2}$ 濃度の結果からも, 冬期の上昇が認め られている。このことにより TVOC 濃度の上昇を招いた可能性があ るため, 定期的な空明け換気及び機械換気の運転により，VOC 濃度 の上昇を防ぐことが重要と考えられる。なお,特に冬期においては, 空空け換気による室温の急激な低下の課題がある。そのため, 常時 の機械換気による全般換気で, 極端に高濃度としないことが重要で あると考えられる。

\subsection{TVOC 濃度}

本調查では, TVOC 濃度が平均約 $2000 \mu \mathrm{g} / \mathrm{m}^{3}$ と暫定目標值を大幅 に上回った住宅が多数あった。TVOC の暫定目標值の設定には，健 康影響を考慮した值ではないものの, 国内における室内化学物質濃 度の実態調查の結果を用いて, 対象となった居室の半数が達成可能 と推定された值である ${ }^{10)}$ 。更には，竣工後の住宅においてはTVOC 濃度が高い状況にあることが述べられている。今回の応急仮設住宅 においてTVOC 濃度が高かった原因としては，換気不足もあると考 えられるが，上述のテルペン類が高濃度であった他に，定性ができ ていないものの溶剤中のミネラルスピリットからと考えられる芳香 族炭化水素類，脂肪族炭化水素類及びナフタレンを含む物質が多く 検出されていた。杉材の小形チャンバー法による発生成分を分析で は ${ }^{23)}$, 同様の物質が検出され, 木材からの発生が考えられる。また, 既往研究 ${ }^{5)}$ では, 酢酸ブチル, メチルイソブチル， $\alpha$-ピネンのほか, テキサノール及びその異性体が多く検出されており，ラテックス塗 料, エマルジョン塗料などの水性塗料の造膜助剤として添加されて いる成分である。厚生労働省の指針值に挙げられている物質以外の VOC の室内における発生が, TVOC 濃度が高濃度の原因となってい 
た。

\section{3 開放型ストーブの影響}

応急仮設住宅には，エアコンが設置されているが，居住者によっ ては, 開放型のガス又は石油ストーブを使用していた。そこで, Fig.5 にトルエン, エチルベンゼン及び TVOC 濃度の夏期と冬期の同一室 内における濃度の関係について示す。ここでは, ヒアリングで暖房 器具の種類を確認し, エアコン・電気ストーブを使用している部屋 （図中で $A / C$ と表記）と, 開放型の石油・ガスストーブを使用して いる部屋（stove）とを分けて示している。

エアコンのみの部屋では, 夏期及び冬期ともに同程度の濃度であ ったが, ストーブを使用した住宅については冬期の方が高くなった。 特にTVOC 濃度については, 顕著であった。ストーブからは, 多く の有機物質が発生することが知られており ${ }^{24)}$, 冬期においては開放 型ストーブの使用が VOC の濃度を押し上げていることが分かった。

\section{4 住宅の仕様による濃度の違い}

測定対象の仮設住宅は大きく分けるとプレハブ建築協会規格建築 部会会員製（Type 1）と同協会住宅部会会員製（Type 2）の2 種類 である。Type 1 については, 既往の研究 ${ }^{25)}$ より気密性能は中間住戸 で5.39 5.87 $\mathrm{cm}^{2} / \mathrm{m}^{2}$, 妻住戸で $6.24 \sim 6.33 \mathrm{~cm}^{2} / \mathrm{m}^{2}$ であり, 次世代省エ ネ基準を満たしていなかった。一方, Type 2 の実測值はないが，一 般的な住宅と同様の仕様から Type 1 よりも気密性能が優れ, 通常の 木造住宅と遜色ない気密性能を有していると考えられる。この $2 つ$ の住宅のタイプ別の VOC 濃度を比較すると, Fig.6のようにトルエ ン, p-ジクロロベンゼン, TVOC については, 夏期及び冬期ともに Type 2 の方が若干濃度が高い傾向となった。よって, 自然及び通風 換気が期待できない場合には, 機械換気を行うことが, 特に気密性 が高い応急仮設住宅については必要であることが言える。

\section{5. まとめ}

本研究では, 入居中における応急仮設住宅内の夏期及び冬期の空 気中 V OC 濃度の測定を行い, その特徴及び濃度が高くなった原因 について検討を行って，以下のような知見を得た。

・室内空気中の VOC について, ホルムアルデヒドは厚生労働省の 指針值と比較すると低い濃度であり, 応急仮設住宅であっても, 十 分に低濃度に保たれていることが分かった。また, アセトアルデヒ ド，p-ジクロロベンゼン，テトラデカンでは指針值を超過する住宅 があり, TVOC については, 平均約 $2000 \mu \mathrm{g} / \mathrm{m}^{3}$ と高い值であった。 ・夏期及び冬期の濃度を比較すると, 夏期の方が V OC の発生量が 多くなるものの, 夏期よりも冬期の方が高くなった物質として, dリモネン及びTVOC であった。暖房期においては換気量が少なくな ったことが要因と考えられる。

・八ウスダスト中のSVOC の含有量については, DBP が平均 $75 \mu \mathrm{g} / \mathrm{g}$, DEHP が $1800 \mu \mathrm{g} / \mathrm{g}$ であり, 既往の研究のアパートにおける含有量に 比較すると若干高い值を示した。また, 冬期の方が空気中濃度も高 い傾向であった。

・TVOC 濃度が比較的高濃度となった原因として, 機械換気を活用 していないことに加え, VOC の成分から木材から発生する物質が多 量に含まれていることから, 構造としている木材からの発生物質が TVOC 濃度を押し上げているのも一つの原因であることを示した。 ・住宅タイプによっては, 気密性能が向上することにより VOC 濃

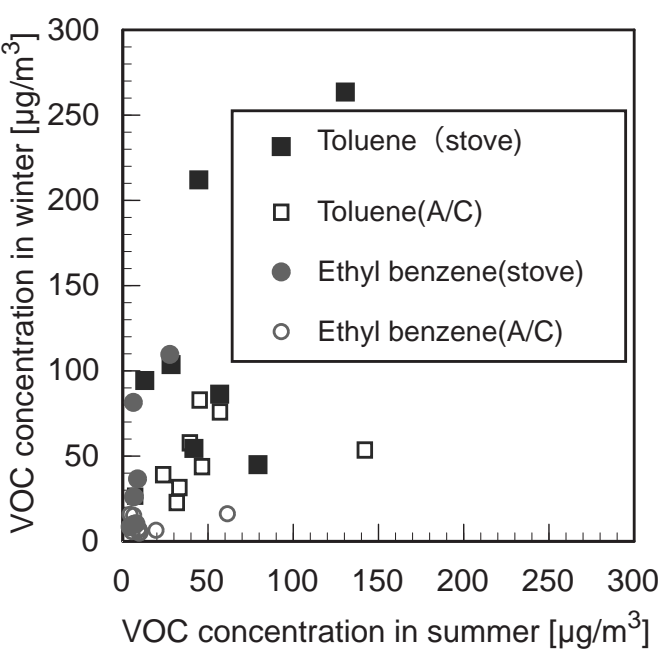

a) Toluene and ethyl benzene

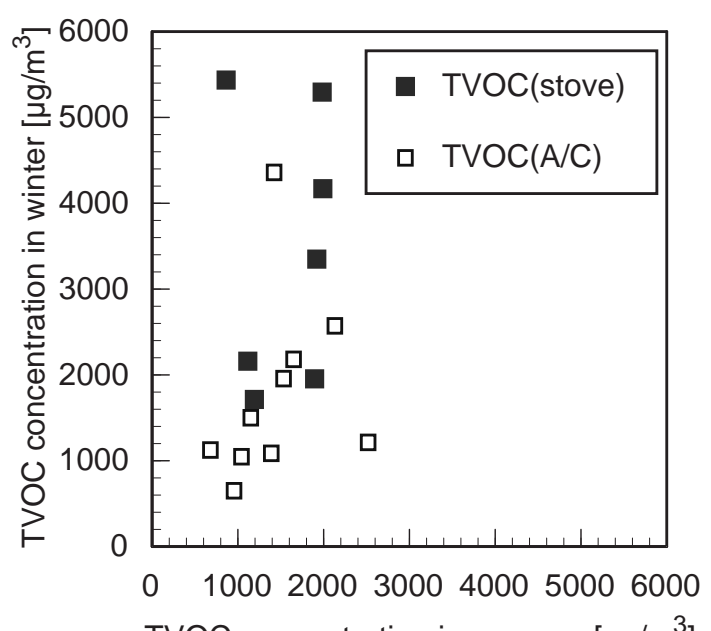

b) TVOC

Fig.5 Relationships of VOC concentrations between summer and winter with types of heating equipments

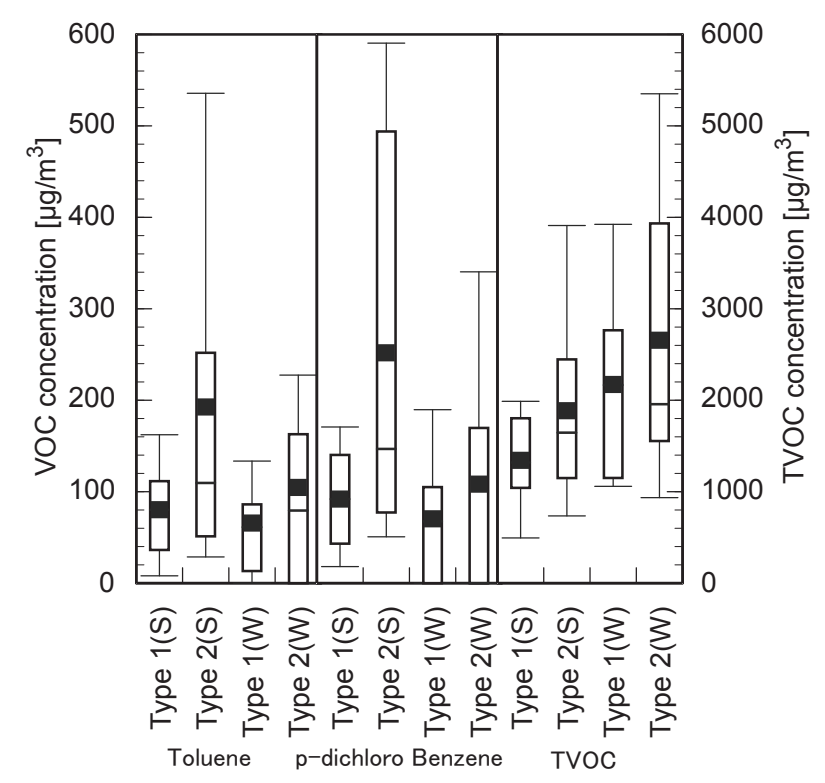

Fig. 6 VOC concentrations with house types 
度に影響を与えていることが明らかになった。

\section{謝辞}

本研究は, 2011 年 3 月 11 日に発生した東日本大震災直後に組織 された「日本建築学会東北支部・環境工学部会・震災関連住宅にお ける健康影響の低減対策に関寸る研究 W G (委員長 : 吉野博 - 東北 大学教授)」の活動の一環として実施したものである。なお, 本調査 は, 秋田県立大学研究倫理審査委員会による審查を経て承認を得た 後に実施している。本調查を進めるに当たっては, 応急仮設住宅を 始め被荻地域に居住されている皆椂に, 多大なるご理解・ご協力を いただきました。ここに記して深甚なる謝意を表します。

\section{参考文献}

1)大澤元毅, 池田耕一, 林基哉, 小島隆矢, 真鍋純, 中林由行 : 2000 年全国 実態調査に基づく住宅室内空気の VOC 污染の状況, 日本建築学会環境系 論文集，第 575 号，pp.61-66，2004.1

2)国土交通省: 平成 17 年度室内空気中の化学物質濃度の実態調査の結果等に ついて, http://www.mlit.go.jp/kisha/kisha06/07/071130_html, 2006.11.30.

3)後藤隆雄, 日埜昭子: 阪神大震災 1 年後の西須磨地域での健康アンケート 調査と二酸化窒素污染の調査との関係について, 自然災害科学, 第 17 巻, 第 3 号, pp. 249-260, 1998.11

4)寺園淳, 酒井伸一, 高月紘 : 阪神・淡路大震災における建物解体にともな るアスベスト飛散に関する検討, 大気環境学会誌, 第 34 巻, 第 3 号, pp. 192-210, 1999.11

5)笈川大介, 高尾洋輔, 村田真一郎, 竹内弥, 下山啓吾, 関根嘉香 : 宮城県 内の応急仮設住宅における室内空気中アルデヒド・ケトン類および揮発性 有機化合物の実態調査, 室内環境, 第 14 巻, 第 2 号, pp. 113-121, 2011.12

6)柳宇, 吉野博, 長谷川兼一, 東賢一, 大澤元毅, 鍵直樹, 猪野玩也：東日 本大震災における応急仮設住宅の空気環境に関する調査研究, 日本建築学 会環境系論文集，第 78 巻，第 694 号，pp. 917-921，2013.7

7)柳宇, 吉野博, 長谷川兼一, 東賢一, 大澤元毅, 鍵直樹 : 仙台市内の応急 仮設住宅における室内真菌污染の実態, 日本建築学会技術報告集, 第 22 巻, 第 51 号, pp. 615-620, 2016.6

8)長谷川麻子, 柳宇, 鍵直樹, 長谷川兼一, 篠原直秀, 阿部恵子, 吉野博 : 阿蘇市における応急仮設住宅の室内空気環境に関する調査研究, 日本建築 学会環境系論文集, 第 81 巻, 第 721 号, pp. 319-325, 2016.3

9) N. Shinohara, M. Tokumura, M. K azama, Y. Y onemoto, M. Y oshioka, N. K agi, K. Hasegawa, H. Y oshino, U. Y anagi: Indoor air quality and thermal comfort in temporary houses occupied after the Great East Japan Earthquake, Indoor Air, Vol. 24, pp. 425-437, 2014, DOI: 10.1111/ina.12082

10) 日本建築学会 : 日本建築学会環境基準 AIJES-A 006-2010 総揮発性有機化合 物による室内空気污染に関する設計・施工等規準・同解説, 2010

11) H. Sagunski, B. Heinzow: Richtwerte für die Innenraumluft: Bicyclische Terpene (Leitsubstanz $\alpha$-Pinen), Bundesgesundheitsbl - Gesundheitsforsch Gesundheitsschutz, Vol. 46, pp. 346-352, 2003.
12) Mitteilung der Ad-hoc-A rbeitsgruppe: Richtwerte für monocyclische Monoterpene (Leitsubstanz $d$ - Limonen) in der Innenraumluft, Bundesgesundheitsbl, V ol. 53, pp. 1206-1215, 2010.

13)千野聡子, 加藤信介, 徐長厚, 安宅勇二 : 各種塩化ビニル床材を施工した 床面からの化学物質放散量測定 : 化学反応により生成した 2-エチル-1-へキ サノールの放散性状, 日本建築学会環境系論文集, 第 74 巻, 第 636 号, pp. 185-191, 2009.2

14) Mitteilung der Ad-hoc-Arbeitsgruppe: Richtwerte für 2-Ethylhexanol in der Innenraumluft, B undesgesundheitsbl, V ol. 56, pp. 590-599, 2013.

15)篠原直秀, 片岡敏行, 高峰浩一, 中村利美, 本橋勝紀, 西島宏和, 佛願道 男, 蒲生昌志 : 26 軒の住宅 3 部屋における換気量の日変動と季節変動, 第 10 回室内環境学会学術大会論文集, pp. 94-95, 2007.12

16)金澤文子，岸玲子：半揮発性有機化合物による室内污染と健康への影響, 日本衛生学会誌, 第 64 巻, pp. 672-682, 2009.5

17) H. Fromme, T. Lahrz, M. Piloty, H. Gebhart, A. Oddoy, H. Ruden: Occurrence of phthalates and musk fragrances in indoor air and dust from apartments and kindergartens in B erlin (Germany), Indoor A ir, 14, 188-195, 2004.

18) A. Kanazawa, I. Saito, A. A raki, M. Takeda, M. Ma, Y. Saijo, R. Kishi: Association between indoor exposure to semi-volatile organic compounds and building-related symptoms among the occupants of residential dwellings, Indoor Air, Vol. 20, pp. 72-84, 2010

19)鍵直樹，並木則和：室内における浮遊微粒子とハウスダストのSVOC，エ アロゾル科学・技術研究討論会, pp. 183-184, 2009

20)Kim Hyun-Tae, 田辺新一, 金泰祐 : 韓国住宅におけるリフォーム前後の八 ウスダスト中 DEHP 濃度と床材からのSVOC 放散速度, 日本建築学会計画 系論文集，第 76 巻，第 665 号, pp. 617-622, 2011.7

21)常本祥子, 岡田厚太郎, 高野修一, 金勲, 田辺新一, 吉野博 : 半揮発性有 機化合物(SVOC)の測定法に関する研究, その 8 住宅におけるハウスダスト 中 SVOC 濃度测定, 日本建築学会大会学術講演梗概集, 環境工学 II, pp. 931-932, 2008

22)大澤元毅, 吉野博, 長谷川兼一, 柳宇, 東賢一, 鍵直樹, 浜田健祐, 猪野 玩也，角間隆之：震災関連住宅における温熱・空気環境に関寸る調査第 3 報 宮城県応急仮設住宅における聞き取り調査の結果, シンポジウム東日 本大震災からの教訓, これからの新しい国つくり, 日本建築学会, pp. 439-442, 2012.3

23)鍵直樹，吉野博，長谷川兼一，柳宇，東賢一，大澤元毅，本間義規，浜田 健祐，猪野环也，角間隆之：震災関連住宅における温熱・空気環境に関す る調査第 10 報 応急仮設室内における揮発性有機化合物の調査結果, シン ポジウム東日本大震災からの教訓，これからの新しい国つくり，日本建築 学会, pp. 467-470, 2012.3

24)野崎淳夫，折笠智昭，吉澤晋：開放型石油暖房器具からの V O C の発生 : 開放型燃焼器具からのガス状污染物質の発生に関する研究 その 1 , 日本 建築学会環境系論文集, 第 591 号, pp.31-35, 2005.5

25)猪野玩也，吉野博，石川善美，浜田健佑：震災関連住宅における温熱 空気環境に関する調査 第 5 報未入居応急仮設住宅における夏期温熱環境 と気密性能の調査結果, 東日本大震災シンポジウム, 日本建築学会, pp. $440-443,2012.3$ 


\title{
FIELD INVESTIGATION ON INDOOR CHEMICAL POLLUTION IN TEMPORARY HOUSES IN SENDAI CITY
}

\author{
Naoki KAGI*, Hiroshi YOSHINO **, Kenichi HASEGAWA ***, \\ U YANAGI ${ }^{* * *}$, Kenichi AZUMA***** and Haruki OSAWA ${ }^{* * * * * *}$ \\ * Assoc. Prof., Tokyo Institute of Technology, Dr.Eng. \\ ** President-appointed Extraordinary Prof., Tohoku University, Dr.Eng. \\ *** Prof., Akita Prefectural University, Dr.Eng. \\ **** Prof., Kogakuin University, Dr.Eng. \\ ***** Assoc. Prof., Kindai University, Dr.Eng. \\ ****** Chief Researcher, National Institute of Public Health, Dr.Eng.
}

The Great East Japan Earthquake had occurred on March 11th in 2011. There were serious damages in Tohoku and Kanto district, especially seaside cities of the Pacific Ocean in Tohoku district by tsunami. Many people in these areas had lost their houses and more than fifty thousand temporary houses were built in three prefectures of the Tohoku district. Several problems, such as indoor thermal environment and indoor air quality as well as sound environment problems might be occurred in temporary houses.

This study aimed to investigate the indoor air quality, especially indoor VOC (volatile organic compound) concentrations in the temporary residential houses. In summer in 2011 and winter in 2012, measurements have been conducted in the temporary houses in Sendai and measuring results were compared with guideline value in Japan.

As a result, the mean concentrations were much less than the guideline values, however acetaldehyde, $p$-dichloro benzene and tetra-decane concentrations in some rooms exceeded the guideline values. Since p-dichloro benzene was emitted from moth-repellent that the residents used, the concentrations in the houses using moth-repellent might become at high level. The a-pinene and d-limonene are emitted from wood materials along with acetaldehyde. Therefore, the reason why the acetaldehyde concentrations were high in indoor air was the emission from woods used as construction and interior materials in the temporary houses. One of the sources of 2-ethyl-1-hexanol in indoor environments is the chemical reaction of the plasticizer contained in vinyl chloride materials. Since the vinyl chloride sheets were used at kitchen floorings in some temporary houses, 2-ethyl-1-hexanol was detected in the specific houses.

TVOC concentrations in every temporary houses exceeded the tentative guideline, $400 \mu \mathrm{g} / \mathrm{m}^{3}$. Since only about $65 \%$ residents of the temporary houses did not generally use the ventilation fans of the toilet or bathroom from the other previous survey, the necessary ventilation air volumes in houses were usually not enough. The acetaldehyde exceeded ratio for the temporary houses was higher than one of the previous survey of newly built houses. The mean TVOC concentration of about $2000 \mathrm{\mu g} / \mathrm{m}^{3}$ showed higher compared with the tentative guideline value. The shortage of ventilation air volume could be also one of the reasons that the TVOC concentrations were high in the temporary houses. The TVOC in the temporary houses contained not only terpens, such as a-pinene and d-limonene, but also the aromatic hydrocarbons, aliphatic hydrocarbons and other many kinds of compounds.

The mean DEHP concentration in house-hold dust was about $2000 \mu \mathrm{g} / \mathrm{g}$. In the previous survey of the 30 apartments and kindergartens, an average DBP was $55.6 \mu \mathrm{g} / \mathrm{g}$, and DEHP was $775.5 \mu \mathrm{g} / \mathrm{g}$. While DBP concentration was at same level, DEHP was much higher than the previous study. Various materials, such as wooden flooring, tatami, and PVC sheet, are used in the temporary houses, and there were various sources of SVOC. The SVOC concentration in settled dust in the temporary houses could be affected by not only the emission source of interior materials but also the duration of exposure and frequency of cleaning on floorings. 